\title{
Türk Dünyasının Entegrasyonunda Lise Edebiyat Tarihi Kitaplarının Yeri ${ }^{*}$
}

\author{
Nâzım Hikmet Polat *
}

Öz

Edebiyat tarihine eğitimin amacı istikametinde bir rol yüklenmesi, modernitenin getirdiklerindendir. Edebiyat tarihinin millî kimlikle birlikte düşünülmesi, önce Batı toplumlarında başlamıştır. Türkiye'de ise edebiyat tarihine böyle bir fonksiyon atfedilmesi ancak 20. yüzyılın başlarında, Balkan Savaşlarından sonradır. Osmanlı dönemindeki ilk edebiyat tarihleri Osmanlıcılık ideolojisine uygun olarak sadece Osmanlı coğrafyası ve tarihi içindeki edebiyatla ilgilenmişler, Türkçenin diğer coğrafyalardaki edebî verimlerini ve daha önceki dönemlerin edebî birikimini yok saymışlardır. İlk defa Köprülüzade Mehmet Fuat, Tarih-i Edebiyat Dersleri nde "bütün Türklük” fikriyle hareket etmiştir. Cumhuriyet döneminde ise II. Dünya savaşına kadar Türk Edebiyatı orta öğretiminde Türkiye dışındaki Türk edebiyatına yani çeşitli Türk lehçelerinin edebiyatına yer verilmiştir. Ancak II. Dünya Savaşı sonrasında Sovyetlerin güçlenmesi, Türkiye’de bütün Türklük fikriyle edebiyat tarihi yazmanın önündeki en büyük engel olmuştur. Orta öğretime paralel olarak üniversitelerde de çağdaş Türk lehçeleriyle yeterince ilgilenilmemiştir. Sovyetler Birliğinin dağılmasından sonra Türk lehçelerinin edebiyatına ilgi artmıştır. Bu bilimsel gayretler, Türk dünyasının entegrasyonunu güçlendirecek, hızlandıracaktır.

\section{Anahtar kelimeler}

Osmanlıcılık, edebiyat tarihi, Balkan Savaşları, Türk lehçeleri, Türk dünyası bütünleşme (uyum).

* Geliş Tarihi: 24 Eylül 2019 - Kabul Tarihi: 17 Ekim 2019

Bu makaleyi şu şekilde kaynak gösterebilirsiniz:

Polat, Nâzım Hikmet (2019). "Türk Dünyasının Entegrasyonunda Lise Edebiyat Tarihi Kitaplarının

Yeri”. bilig - Türk Dünyast Sosyal Bilimler Dergisi 91: 255-278.

"* Prof. Dr., Ankara Hacı Bayram Veli Üniversitesi, Edebiyat Fakültesi, Türk Dili ve Edebiyatı Bölümü - Ankara/Türkiye

ORCID ID: https://orcid.org/0000-0001-5734-9308

nazim.polat@hbv.edu.tr 


\section{Giriş}

Bir bilim dalı olarak edebiyat tarihi, toplumsal değişmeleri, edebî birikim üzerinden inceler. Fertlerin günlük hayat uğraşlarından milletlerin gelecek tasavvurlarına kadar akla gelebilecek her şey edebiyata yansır. Bundan dolay1 edebiyat tarihi, Gustave Lanson'un tespit ve yorumuyla medeniyet tarihinin bir cüzü sayılmıştır. Bütün toplumbilimciler, bir milletin medeniyet âlemindeki yerini en iyi gösterebilecek aynanın edebiyat tarihi olduğunda hemfikirdirler. Türk dünyasının bütünleşmesi, Türk aydınlarının en az bir buçuk asırlık meselesidir. 11. yüzyıldan itibaren Türk yazı dilinin farklı kollara ayrılması, kültürel birlikteliğin gittikçe zayıfladığı yolunda bir endişe doğurmuş ve buna çareler aranmıştır. Namık Kemal'den Ahmet Midhat'a, Azerbaycanlı aydın Mirza Fethali Ahundof'tan Tevfik Fikret'e kadar edebiyat ve fikir alanında pek çok kalem sahibi, ortak dil konusunda düşünce belirtmişledir. İsmail Gaspıralı ise bunu "İşte, fikirde, dilde birlik" şeklinde bir formül hâline getirmiştir. Konuyla ilgili gayretler doğal olarak Türkçülük çerçevesindedir. Ancak Türkçülük fikri de yine doğal olarak Türk dünyasının entegrasyonu ile ilgilenmiştir. Mevcut birlikteliğin ne derecede olduğu, daha ileri aşamalara nasıl varılabileceğine dair tespit ve öneriler, iktisadi alanda çeşitli istatistik sonuçlarıyla desteklenebilir. Siyasi alandaki bütünleşme, ortak vatandaşlıktan ortak parlamentolara, benzer yönetimlere, benzer yasalara kadar varabilir. Kültürel alandaki bütünleşmenin gösterge alanları ise iktisadi ve siyasi alandakilerden oldukça geniş çerçevelidir. Ancak ortak kültür unsurlarının sonraki nesillere aktarımı konusunda en uygun vasıta, her türlü sanat dallarındaki eserler, tarih çalışmaları ve edebiyat tarihleridir. Kökleri ne kadar önceye uzanırsa uzansın, edebiyat tarihçiliğinin bağımsız bir bilim dalı olarak ortaya çıkışı sadece Türkiye için değil Batı dünyası için de çok eski sayılamaz. Nitekim edebiyat tarihinin diğer tarih dallarından ve eleştiriden farklı bir bilim dalı olarak kabulü ancak Fransız düşünür ve bilim adamı Hippolyte Taine'in History of English literature (1871) adlı eserine kadar götürülebilmektedir. Biraz daha zorlamayla, ilkeleri Hippolyte Taine kadar netlik kazanamamış olan Désire Nissard'ın Histoire de la littérature française (1844-1861) ve Études d'histoire el de littérature (1859-1864) adlı eserlerine kadar gidilebilmektedir. Gustave Lanson, 1909'da hazırladığ 1 "Méthodes de L'historie Littéraire" (Edebiyat Tarihinde Yöntem) adlı çalışmasıyla, bu alandaki nazarî (teorik) birikimi daha olgun bir seviyeye yükseltmiştir. Bu makalenin büyük ölçüde benzeri olan bir makale de Türkçede 
Köprülüzade Mehmet Fuat tarafından "Türk Edebiyatı Tarihinde Usul" (Bilgi Mecmuası, Sayı: 1, Teşrinisani 1329 [Kasım 1913], s. 3-52) başlı̆̆ıyla yayımlanmıştır. Daha sonraki yıllarda bu çalışmaların işaret ettiği teorik çerçeveye önemli bir ilave yapılmamıştır. Gelinen noktada edebiyat tarihi, yukarıda söylendiği üzere, bir dilin ve o dili kullanan halkların yaşayış ve düşünüşlerinin bir aynası kabul edilmektedir. Bu itibarla edebiyat tarihleri, yazıldığı dönemin birikimini değerlendirerek Türk dünyasının entegrasyonu konusundaki niyet ve eylemleri tespitte en önemli kaynaklardandır.

Orta dereceli okul programlarına edebiyat tarihi dersleri ilk defa Osmanlı döneminde 1909-1910 ders yılında koyuldu (Levend 1973: 480). Dersin adı, "Osmanlı Tarih-i Edebiyatı" idi. Cumhuriyet Döneminde ise orta dereceli okullarda "Edebiyat Tarihi" dersi okutma kararı, 1924'te verilmiştir (Yücel 1994: 184-185). İçeriği küçük değişikliklere uğrasa da bu ders, 1945 'teki köklü program değişikliğine kadar varlığını sürdürmüştür. Türkiye'de yayımlanan edebiyat tarihlerinin 30 'u bu tarihe kadar basılmıştır ve tamamı lise ders kitabı veya yardımcı kitaptır. Söz konusu eserler bir programa mutabık olarak yazıldıklarından dolayı az-çok devrin sosyal ve siyasî zeminini anlamada, ihmal edilemeyecek bir vasıtadır. Bütün kültür dersleri gibi edebiyat tarihi dersleri de Türk dünyasının, fikir planında ortaklığa (entegrasyona) götürme yolundaki araçlardandır.

Bu makalede, ders kitabı veya edebiyat tarihi olmayan iki eserdeki (Harabat ve Tarihçe-i Lisan-ı Osmani) Türklük algısına temas edildikten sonra Türkiye'de yayımlanmış bu ders kitaplarının Türk dünyasının bütünleşmesi konusundaki tavırları incelenecektir. Ders kitabı veya yardımcı kitap olmayan edebiyat tarihlerinde Türkiye dışındaki Türklerin edebî birikimini değerlendirmek, entegrasyona katkı olmaktan çok mücerret bilim gayreti taşıdıkları için bu yazının çerçevesine dâhil edilmemiştir.

\section{Osmanlı Döneminde}

Henüz edebiyat tarihi yazılmadan önce bu bilim alanına hazırlık çalışmalarından bahsedilebilir. Söz konusu çalışmaların en önemlisi Ziya Paşa’nın Harabat adlı antolojisidir. Eserin manzum ve kronolojiyi gözeten mukaddemesi küçük bir edebiyat tarihi sayılabilir. Antolojinin yazılma sebebini dile getiren "Sebeb-i Tertib-i Harabat" (Kaplan, Enginün ve Emil 1978: 50-55) kısmında Osmanlı sahasındaki şairlerin İran şairlerini taklit ettikleri, aslında 
bu taklidin ta Ali Şir Nevayî ile başladığı söylenmektedir:

Ettim şuara-yı Rûm'u tahkik

Asâr u zamanlarıyla tatbik

Gördüm olmuş halef-selef hep

İran şuarasına halef hep

Evvel söze başlamış Nevâyî

Taklit ile Farisî edâyı

Gelmişşuarâ-yı Rum pişin (Kaplan, Enginün ve Emil 1978: 51)

Burada konumuz açısından önemli taraf, Anadolu'daki (Osmanlı sahası) Türk şiirinin Doğu Türklüğünden bir şaire (Nevayîye) bağlanmış olmasıdır. Aynı bölümde doğu Türkçesine ("Çağatayca”) ait seçmelere yer verilişi şöyle açıklanmıştır:

Çünkim bu dile misâl-i mâder

Oldu Çağatay lisânı masdar

Terkeylemeye hicap ettim

Andan dahi intihap ettim

Malum ola tâ zaman ne olmuş

Evvel ne imiş lisan ne olmuş.

Yukarıdaki beyitlerle Ziya Paşa açıkça, Osmanlı sahası Türkçesinin edebî geçmişini Çağatay (Nevayî) Türkçesine bağlamaktadır. Bu ifadelerin verdiği bilgi, bugün çok sıradanlaşmıştır. Fakat bir "Osmanlı milleti” inşası için bütün devlet kademelerinin gayret gösterdiği bir dönemde, doğu Türklüğü ile olan birlikteliğin hatırlatılması önemlidir.

Edebiyat tarihi olmamakla birlikte Osmanlı sahası Türkçesinin tarihî gelişimi üzerine kısa bir dil tarihi denemesi diyebileceğimiz Tarihçe-i Lisan-ı Osmanisinde (Mehmet Fuat), Türkçenin konuşulduğu bölgeler ("Sibirya, Afganistan, Türkistan, Kafkasya”) sayılıp, Osmanlı Türkçesinin Doğu Türkçesiyle irtibatına temas edilmiştir. ${ }^{1}$

Türkiye'de yayımlanmış ilk edebiyat tarihi olan Abdülhalim Memduh'un Tarih-i Edebiyat-ı Osmaniye (1888) isimli eseri Osmanlı sınırları dışıyla hiç mi hiç ilgilenmez. Şahabettin Süleyman'ın idadilere ders kitabı olarak hazırladığı Tarih-i Edebiyat-ı Osmaniye’nin (1328/1910) “Osmanlı Lisanı” (7- 
13) kısmında yazdıkları, daha sonra başkaları tarafından da tekrarlanmıştır:

Türkistan teşkilat-1 kadimesi itibariyle Tatarlardan, Harezmilerden, Buharalılardan mürekkep olup İslamiyet' in zuhurundan beri Türkmenler, Tatarlar, Moğollar, Uygurlar gibi birtakım kabâile ayrılmış (...) idiler. Hatta bunlar Asya-yı Sugra’nın ortalarına kadar geldikleri gibi Avrupa’yı da istila etmişlerdi. İşte bunlardan Selçukîler iptida Anadolu’da tesis-i hükümet ederek Anadolu’yu Türkleştirmişler, oraya Türk neslini getirmişlerdir.

Osmanlıların cedd-i âlâsı Süleyman Şah, Türkistan'da bir kabile reisi iken Cengiz'in tecavüzatından kurtulamayarak iptida Horasan’a, oradan da İran'ı dolaşarak Asya-yı Sugra’ya girmişti (...). Osmanlılar, tamamıyla tesis-i istiklâl etmeden karşılarında eskiden gelmiş, o zamanın merkez ziyâ-yı maarifi, menba-1 sanatı olan İran'ın tarz-1 inşasını lisan-1 resmîsi ittihaz etmiş, hatta kendi lisanını eski, kaba şekilden çıkarmak için hâl-i tekâmülde bulunan İran lisanıyla Arap lisanından birçok kelimeler kabul etmiş Selçukî Türkleriyle, ba’de Türkistan`dan akın akın gelen Türkmen, Türk aşâirini Anadolu’nun daire-i İslamiyet'e girmiş eski ahalisini bulmuştu.

Şahabettin Süleyman'ın sıradan tarih bilgilerini aktardığı açıktır. Fakat bu alıntı metnin önemi, edebiyat tarihinin mihveri olarak dil ve milliyeti almasıdır. Yine de ders programı gereği, "Osmanlılık" dışına çıkamadığı, Türkiye dışında kalan Türklerin 15-19. yüzyıl arasındaki edebiyatlarından hiç bahsetmediği görülmektedir. Aslında Osmanlı dönemi Türk aydınlarının çoğu devleti ve siyasi sınırları esas aldığı için Türk dünyasının diğer bölgeleriyle hiç ilgilenmemişlerdir. Hatta Osmanlı sınırları dışında kalan bir isimden bahsedilmesini bile şaşkınlıkla karşılayan Osmanlı edebiyatı tarihi yazanlar vardır. Mesela Faik Reşat Tarih-i Edebiyat-ı Osmaniye'sinde (1912) Ziya Paşảnın Harabat'ta (yukarıda bahsedildiği üzere) Ali Şir Nevayi'den söz etmesini şöyle eleştirmiştir:

Âsâr-1 eslafı en ziyade tetkik edenlerden binaenaleyh bu yolda en ziyade sahib-i ihtisas olanlardan biri de Ziya Paşa merhum zannolunur- du. Hâlbuki tetkikatının ne derecede nakıs, 
tarih-i edebiyatımız hak- kındaki malumat ve içtihadatının ne kadar hata-âlûd olduğunu Harabat’a yazdığı mukaddime gösteriyor. (...) Bir kere ahvâl-i şuarâ-yı Rum'dan bahis olunduğu sırada Türkistanlı, daha doğrusu Acem olan, binaenaleyh Osmanlılıkla kat’a alaka ve münasebeti olmayan Ali Şir Nevayî̀yi kaale almakta ne mana vardır, bilinemez. Sânîyen eğer maksat iptida Türkçe şiir söyleyen Nevayîdir demek ise kendisi Fatih asrında yaşamış bir şair olarak hâlbuki ondan asırlarca evvel, hem de Çağatayca değil, Osmanlı Türkçesi ile şiir söyleyenler vardı... (Faik Reşat 1912: 26-27).

Faik Reşat, Osmanlı edebiyatını doğu Türklüğünün edebiyatından tamamen aynı görmek yanında Anadolu Türklügüunden oldukları halde Osmanlı Devleti vatandaşı olmayan Mevlana, Sultan Veled ve Süleyman Çelebi'ye bile itiraz eder. Namık Kemal, Tahrib-i Harabat'ta (1874) Ziya Paşa'yı tenkit ederken onun Mevlana, Sultan Velet ve Süleyman Çelebi'ye Harabat'ta yer vermemesini eleştirmişti. Faik Reşat ise Namık Kemal'in bu eleştirisini isabetsiz bularak der ki:

...Hazret-i Mevlana (...) beş on beyitten başka Türkçe şiir söylemedikleri ve onlar da Türkçe olmaktan ziyade Çağatayca olduğu ve bahusus kendileri Devlet-i Osmaniyenin tesisinden otuz sene mukaddem irtihal buyurdukları cihetle müşarünileyhi Osmanlı ve Osmanlı şairi addetmeye imkân yoktur. Gerçi Sultan Velet Hazretleri, Osman Gazi zamanını idrak etmiş iseler de asla Osmanlı mülküne ayak basmamış ve (...) yalnız bir iki gazel ile Rebabname ismindeki mesnevilerinin yüz altmış bu kadar beytini Türkçe nazmetmişlerdir (Faik Reşat 1912: 30).

Özetle Faik Reşat, siyasi sınırları aşamayan, devlet ile edebiyatı meydana getiren dilin ayrı şeyler olduğunu kavrayamamış, meseleyi şahısların hal tercümeleri sanan anlayışa mağlup düşmüştür. Yeni Lisan tecrübesiyle, edebiyata dil ve milliyet açısından bakma eğiliminin arttığı bir dönemde devleti ve onun vatandaşlığını esas almak yalnızca alışkanlıklara takılıp kalmakla açıklanabilir. Fuat Köprülü, onun bu ilkesini gözden kaçırmış olmalı ki yazarı Kadı Burhaneddin, Sinan Paşa, Yunus Emre gibi birtakım şahsiyetleri ihmal etmekle eleştirmiştir (Köprülü 1913: 2). 
Aynı yıl (1912) Mehmet Hayrettin'in yine aynı adla (Tarih-i Edebiyat-ı Osmaniye) yayımladığı kitap, Şahabettin Süleyman'ın yukarıda bahsedilen eserinin özeti mahiyetindedir ve "Yeni Lisan" taraftarlığına rağmen "bütün Türklük” fikrinden mahrumdur.

Bütün bu eserlerin Osmanlı sahası dışındaki Türkçenin verimlerine adeta göz kapamasına rağmen Azerbaycan'da Ferhat Ağazade tarafından kaleme alınan Edebiyat Mecmuası (1912) adlı bir orta öğretim ders kitabında "Türk Edebiyatı" başlıklı kesimde Ali Şir Nevayî (s. 94-95), Fuzulî (s. 95-99), Seyyit Ebülkasım Nebati (s. 99-101), Ziya Paşa (s. 101-107), Muallim Naci (s. 107-113), Namık Kemâl (s. 113-136), Şemsettin Sami (s. 136-153), İsmail Safa (s. 153-156), (Recaizâde) Ekrem (s.156- 188), Abdülhak Hamit (s.158162), Ahmet Hikmet Bey Sezaizade ${ }^{2}$ (s. 162-165), Uşşakizade Halit Ziya (s. 165-167), Tevfik Fikret (s. 167-179), Abdullah Cevdet (s. 179-182), Ahmet Midhat (s. 183-188), Mehmet Emin (s. 188-195), Samipaşazade Sezai (s. 195-205), Hüseyin Cahit (s. 205-208) gibi Türk dünyasının çeşitli bölgelerinden yazar ve şairden metinler alınmıştır. Ali Şir Nevayi, bugün Batı Türkistan'da (Özbekçe) ve Doğu Türkistan’da yaşayan Türkçenin (Uygurca) yazı dili olarak ilk şeklini; Fuzulî, Seyyit Ebülkasım Nebati Azerbaycan sahasını ve diğerleri Osmanlı sahasını temsil etmektedir.

Denebilir ki diğer Türk bölgelerindeki edebiyatla ilgili ders kitaplarında aynı hassasiyetle davranılsaydı, Türk dünyası; I. Dünya Savaşı sonrasında yaşadığı kültürel kopma ve dağınıklığı, daha az zararla atlatabilecekti.

Yukarıda ele alınan Osmanlı edebiyat tarihlerinin ortak özelliği, başlangıç olarak Osmanlı devletinin kuruluşunu, mihver olarak Osmanlı vatandaşl1ğını kabul etmeleridir.

Balkan Savaşları, batı Türklüğü için tam bir varlık-yokluk mücadelesi olmuş ve komşuluk münasebetlerinden, Mebusan Meclisine milletvekili seçimine varıncaya kadar hayatın her alanına "milliyet" merkezli bakmayı gerekli kılmıştır. Nitekim bu tarihten sonra Türkiye'de yazılan edebiyat tarihlerinde Osmanlı öncesine de yer verilmeye başlanmıştır. Söz konusu tercih, Osmanlı sahası dışında kalan Türklükle ortak tarih ve ortak kültür unsurlarına bir köprü kurmak anlamına gelmektedir. Sözgelimi Şahabettin Süleyman ile Köprülüzade Mehmet Fuat'ın birlikte sultanilere (liselere) ders kitabı olarak hazırladıkları Yeni Osmanlı Tarih-i Edebiyatı (1332/1914) kitabın oldukça 
kapsamlı yöntem bilgilerinin yer aldığı "Mukaddime"den (s. 3-64) sonra Osmanlı dönemi ve sahası Türk edebiyatına zemin döşemek anlamında bir de "Medhal" (Giriş: 65-130) bulunmaktadır. "Medhal"de Türkler lisanları, medeniyetleri, Türk edebiyat-1 kadimesi, Mevlana Celalettin, Sultan Velet, Yunus Emre, Hükümet-i Osmaniye'nin teşekkülünden evvel Anadolu Türkleri: Selçukîler, medeniyet ve lisanları gibi bahisler vardır. Bu alt başlıklar, eserde coğrafya ve siyasi sınırların aşıldığını, Osmanlılığın yerini "bütün Türklük” fikrinin aldığını gösterir.

Köprülüzade Mehmet Fuat'ın aşağıda bahsedilecek olan iki eseri, orta öğretim ders kitabı değildir ama kendisinden sonraki edebiyat tarihlerini yönlendirici tarafıyla konumuzu ilgilendirmektedir. Fuat Köprülü, Ziya Gökalp’in etki dairesine girdikten ve Darülfünun Türk edebiyatı müderrisi olarak atandıktan sonra "Türk" kelimesi bulunan ilk edebiyat tarihini yazdı: Türk Tarih-i Edebiyatı Dersleri (I. C 1329/1913, II. C 1330/1914). Eserin ilk cildinde "Türk lisanı ve taksimatı, Yazı, Türklerde esatir ve efsane, Türklerde din ve âdet, medeniyetleri, Türk edebiyat-1 kadimesi” gibi konuların bulunması, daha önceki edebiyat tarihlerinden ne kadar farklı olduğunu açıkça ortaya koyar. Yani bu eser edebiyat tarihini artık ait olduğu dil ve millet mihverine yerleştirmiştir. Nitekim eserin ikinci cildinin açıklayıcı başlığı "Osmanlılarda..." değil "Batı Türklerinde edebiyat ve şekl-i tekâmülü” dür. Ayrıca "Osmanlılıktan evvel Anadolu'da hayat-1 fikriye” başlığına ve Osmanlı devleti vatandaşı olmayan Mevlana, Sultan Velet ve Yunus Emre gibi Türk şairlerine yer verilmiştir. Köprülü’nün bu eseri orta öğretim ders programılla sınırlı olmadığı için eserin muhtevasını şekillendirmede daha serbest davranıldığı anlaşılmaktadır.

Yine Fuat Köprülü’nün 1920-1921 yıllarında basılan iki ciltlik Türk Edebiyatı Tarihinnde "bütün Türklük" fikri daha da kökleşmiştir. Nitekim yazar, herhangi bir coğrafyada ve herhangi bir dönemdeki Türk edebiyatının anlaşılabilmesi için diğer coğrafyalardaki edebiyatlarla ve önceki dönem edebiyatlarıyla karşılaştırmalı biçimde incelenmesi gerektiğini belirtmektedir. Bu tespitin anlamı, o sıralarda mevcut edebiyat tarihi kitaplarının yöntem bakımından eksik ve yanlışlarını ortaya koymaktır:

... Başlangıç: Adalar Denizi kıyılarından Çin hudutlarına kadar uzayan vasi bir sahada, muhtelif zamanlarda, muhtelif tesirat altında yaşayan Türklerin asırlardan beri vücuda getir- 
dikleri eserleri tetkik ederek uzun tahlillerden sonra umumî bir terkip yapabilmek, itiraf etmeli ki, adeta imkânın fevkinde bir iştir. Böyle bir terkibin meydana çıkması, Türklerin millî medeniyet tarihinin tenevvür ve tavazzuhu [aydınlanması ve ortaya çıkması] demek olacaktır. (...)

Türk edebiyatı, en eski menşelerden bugüne kadar bütün Türk lehçelerinin yekdiğeriyle olan rabıta ve münasebetleri gözetilerek muntazam bir "küll” şeklinde tetkik olunmadıkça kabil değil tenevvür edemeyecektir. Türk tarihinin şimdiye kadar bir "küll" gibi, hadiselerin bütün rabıtaları meydana çıkarılarak tetkik edilmemiş olması, bundan böyle de aynı yanlış ve gayr-1 ilmî yolun takip edilmesi için hiçbir hak vermez. Mesela Osmanlı tarih-i siyasî ve edebîsinin Maveraünnehir tarih ve edebiyatının, Selçukî tarihinin hulasa umumî Türk tarihine ait bütün fasılların birbirinden tamamıyla müstakil addedilerek mahdut ve mücerret bir surette tetkiki neticesinde, bugün millî tarihimiz kesif bir karanlık içinde kalmıştır. (...) Bu yanlış ve gayr-1 ilmî telakki sebebiyle, Türk edebiyatının menşe ve tekâmülü, muhtelif lehçeler edebiyatının tarz-1 teşekkül ve teşî̉bi [kuruluş ve dallanması], aralarındaki farklarla hudud-1 müşterekelerinin mahiyetleri hakkında henüz en basit ve iptidai bir faraziye bile serd olunamadığını göreceğiz”. (Köprülü 1921: 5-7)

İlk defa Köprülü’nün bu eserinde (1921: 7) Türk edebiyatının gelişimi medeniyet dairelerine göre tasnif edilerek bugün de geçerli olan ilk basamak sinıflamasını

1. İslamiyet'ten evvel Türk Edebiyat1,

2. İslam medeniyeti tesiri altında Türk edebiyatı,

3. Avrupa medeniyeti tesiri altında Türk edebiyatı

şeklinde yapmıştır. Böyle bir tasnif Türk edebiyatını, tarih boyunca bütün Türklüğün yansıdığı bir bilim alanı olarak görmek demektir. İki cilt halindeki bu eser daha çok İslamiyet'in Türkler tarafindan kabulünden önceki ortak dil ve edebiyat dönemleriyle ilgilidir. 


\section{Cumhuriyet Döneminde}

Türkiye'de Cumhuriyet rejimini Türkiye Büyük Millet Meclisinin açllş̧ıla (20 Nisan 1920) başlatmak yanlış değildir. Cumhuriyetin gerektirdiği her şey vardır ve uygulanmaktadır ancak rejim adının ilanı için uygun zaman beklenmiştir. İstanbul'da Osmanlı hükümeti ve onun Maarif Nazırı (Rumbeyoğlu Fahrettin Paşa), Ankara’da ise Türkiye Büyük Millet Meclisi hükümetinin Maarif Vekili (Hamdullah Suphi Tanrı̈ver) vardır. Millî Mücadele’nin başarıya ulaşıp ulaşamayacağının henüz belli olmadığı bir ortamda, Ankara’da Darülmuallimîn salonunda 15 Temmuz 1921- Cuma günü Birinci Maarif Kongresi toplanır (Akyüz 1983: 101-102). Hâkimiyet-i Milliye gazetesinin "İki Cephe” başlıklı haber-yorumunda vurgulandığı üzere Cuma gecesi Erkân-1 Harbiye’de güneşe kadar harbi takip eden hükümet reisi Mustafa Kemal Paşa, dört saat sonra Maarif Kongresini açar. Açı̧ konuşmasında vurguladığı nokta, eğitimin yabancı etkilerden kurtarılmasıdır:

Şimdiye kadar takip olunan tahsil ve terbiye usûllerinin milletimizin tarih-i tedenniyatında en mühim bir amil olduğu kanaatindeyim. Onun için bir millî terbiye programından bahsederken, eski devrin hurafatından ve evsafı fitriyemizle hiç de münasebeti olmayan yabancı fikirlerden, Şark'tan ve Garp'tan gelebilen bilcümle tesirlerden tamamen uzak, seciye-i milliye ve tarihiyemizle mütenasip bir kültür kastediyorum. (...) Lalettayin bir ecnebi kültürü şimdiye kadar takip olunan yabancı kültürlerin muhrip neticelerini tekrar ettirebilir. Kültür, zeminle mütenasiptir. $\mathrm{O}$ zemin milletin seciyesidir (Akyüz 1983: 93).

Köprülüzade Mehmet Fuat'ın yukarıda bahsedilen Türk Edebiyatı Tarihi de yazarın Ziya Gökalp’ın kültür çevresine girdiği dönemden beri söyleyip yazdıklarına uygun bu toplumsal ve siyasi zeminin ürünüdür. Köprülü’nün açtığı çığır, daha sonraki yıllarda da aynı ruhla devam etmiş, edebiyat tarihi ders kitapları "dil" ve "millet" mihverinde yazılmıştır. Yeni bir devlet kurulduğuna göre Osmanlıcılık anlayışı zaten devam ettirilemezdi. Doğru olan, Türkçe eser verilmiş her yerin, edebiyat tarihçisinin dikkati çerçevesinde bulunmasıdı. Nitekim erken Cumhuriyet döneminde yani Atatürk döneminde (veya II. Dünya Savaşı'na kadarki dönemde), en eski Türk tarihine kadar inilerek Türk dünyasının kültürel olarak bütünleşmesi fikrine, 
edebiyat tarihi derslerinin de ayak uydurduğu anlaşılmaktadır.

Bu tür kitapların ana çizgileri medeniyet dairelerini takip etmekteydi, bugün de öyledir. İlgili eserler İslamiyet öncesini ele aynı medeniyet dairesinin dil ve edebiyat verimlerini destanlardan başlatır Orhun yazıtları hakkında bilgi verirler. İslam medeniyeti dairesindeki edebiyat genellikle asırlık zaman dilimi üzerinden ve Batı Türkçesi (Osmanlı ve Azerbaycan) sahası ağılıkta olmak üzere diğer sahalardaki dil ve edebiyat birikimi de verilmiştir. Batı medeniyeti dairesindeki üçüncü halka ise 19. yüzyıl ile gelen dönemi ifade etmektedir. Bu üçüncü halkanın edebî verimler bakımından öncekilerle mukayese edilemeyecek kadar zengin olması, edebî anlayışlar ve toplulukları alt başlık olarak ortaya çıkarmışır.

İbrahim Necmi Dilmen, Galatasaray Mekteb-i Sultanisinde edebiyat tarihi öğretmeni olduğu yıllar, okuttuklarını Tarih-i Edebiyat Dersleri 1. C., Eski Edebiyatımızın Tarihine Seri Bir Nazar; 2. C., Edebî Teceddüdümüzün Zuhur ve Tekâmülü (1338 [1922]) adıyla kitaplaştırmıştır. Resmen bir ders kitabı değilse de yazar tarafından ders kitabı olarak nitelendirilmektedir (3). Eserde sadece, Türkçenin lehçelere ayrılmadan önceki verimleriyle ilgili notlar bulunmaktadır. Hâlbuki yazar hiç olmazsa Azerbaycan'daki kültür ve edebiyat hayatından bahsedebilirdi. Çünkü o sıralar Sovyet blokunun duvarları henüz kalınlaşmamıştı. Azerbaycan'daki bir ses, Türkiye'de, Türkiye'deki Azerbaycan'da duyulabiliyordu. Nitekim 1924 'te Azerbaycan aydınlarından Abdullah Şaik (Talipzade Abdulla Ahund Mustafaoğlu, 1881-1959), orta dereceli okulların birinci ve ikinci sınıflarına mahsustur Türk Edebiyyatı adlı bir kitap yayımlayıp Recaizade Mahmut Ekrem, Mehmet Emin Yurdakul, Tevfik Fikret, Ruza Tevfik, Ziya Gökalp, Cenap Şahabettin üzerinden Türkiye’deki edebî ve kültürel hareketliliği göstermişti.

Cumhuriyet rejiminin resmîleştiği dönemin ilk edebiyat tarihi kitabı, rejimin adının koyulmasından iki hafta önce (15 Teşrinisani / Ekim 1339 / 1923) yazılıp bitirildiği anlaşılan ancak basımı 1925'e taşan Türk Teceddüt Edebiyatı Tarihidir. Eser sahibi İsmail Habip Sevük, Türk edebiyatının tarihini yazmanın diğer milletlerinkini yazmaya benzemediğini söyleyerek işin zorluklarını sıralamışıı. Bunların başındaki sebep Türklerin farklı coğrafyalara dağılmaktan dolayı edebiyatlarının da farklı lehçelerle gelişmişliğidir. Toplu bir edebiyat tarihi yazabilmek her bir lehçedeki birikimi ayrı ayrı ele aldıktan sonra olabilecektir. Ayrıca farklı medeniyet dairelerine girmekten 
dolayı, edebiyatı doğuran cemiyet şartlarının, alınan örneklerin değişmesi de edebiyat tarihçisinin önüne başka zorluklar çıkarmaktadır.

Yazar daha sonra Türk edebiyatının farklı kollarda gelişmesini özetler. Sıra Batı medeniyeti dairesine geldiğinde, "Fransız Tesiratı" başlı̆̆ı altında 1719. yüzyıl Fransız kültür ve edebiyat hayatını gözden geçirir. Kitabın son bölümü, içinde yine Fransız edebiyatına temas eden bir kısmın (Muasır Fransız Edebiyatı) da bulunduğu "Millî Cereyan Edebiyatı"dır (596-690). Ancak kitabın 19. ve 20. yüzyıllardaki Türkiye dışındaki Türk edebiyatıyla ilgili bir bahsi yoktur.

İsmail Habip Sevük'ün, liseler için yazdığı Edeb̂̂ Yeniliğimiz (1932) adlı kitabının I. cildi Tanzimat Edebiyatı'ır ve sadece Osmanlı Türkiye'sindeki kültür ve edebiyat hareketlerine yer vermektedir. Eserin II. cildinde de Türkiye dışındaki edebiyatla doğrudan ilgili bir bahis yoktur. Fakat II. Meşrutiyet yıllarındaki kültürel faaliyetlere zemin olmak üzere "Türkçülük cereyanının tarihçesi” ni verirken "Tanzimat Türkçülüğü” bahsinde "Haricî Türklerden iki sima” başlığı altında Fethali Ahundof ve Buharalı Şeyh Süleyman Özbeki'nin edebî ve kültürel gayretlerini anlatır (384-388). Ayrıca daha sonraki zaman dilimleri için "Vatan haricinde Türkçülük hareketleri” olarak Cemalettin Efgani, Gaspıralı İsmail, Hüseyinzade Ali Turan'dan, Baküde çıkarılan Ekinci (1875) Tiflis'te Ünsizade Celal ve Sait kardeşlerin çıkardığı Ziya-yı Kafkas gazetesinden, Kazanlı Şahabettin Mercani'nin Müstefidül-ahbar adlı tarih kitabından ve Mısır'da Türk gazetesi çevresindeki Türkçülük çalışmalarından bahseder (397-401).

İsmail Habip Sevük'ün eserleri, bilimin kuru diliyle değil edebî bir üslûpla kaleme alındığı için erken Cumhuriyet yılları nesilleri üzerinde diğer edebiyat tarihi ders kitaplarından daha etkili olmuştur.

Muvaffak Hüsnü Benderli, lise 1, 2 ve 3. sınıfları ile olgunluk sınavları için çeşitli ders kitaplarından çıkardığı özetlerden Edebiyat ve Edebiyat Tarihi (1933) adlı bir kitap yayımlamıştır. Devrin Türkiye dışındaki Türklüğe ilgisini en iyi gösterebilecek olan bu eserin planı, üç medeniyet dairesiyle uyumlu başlıklardan sonra asır asır ilerlemektir. İslami Türk Edebiyatı kısmında her yüzyıl için ayrı bir başlık açılmış ve farklı lehçelerin ve coğrafyaların edebî faaliyetlerine ayrı ayrı temas edilmiştir. 19. yüzyıla kadar bütün Türk dünyasının edebî verimleri eşzamanlı olarak gösterilmiştir. Ancak 19. 
yüzyılda sadece Azerbaycan ve Osmanlı sahası üzerinde durulmuştur. Çünkü 17. ve 18. yüzyıllar boyunca hanlıklar arasındaki iç mücadeleler ve bundan istifade ile hemen hemen bütün Türkistan'ı kasıp kavuran Rus istilası, eski verimliliğin devamına imkân bırakmamıştır.

Benderlioğlu, kısmen bir canlılığı bulunan Azerbaycan sahası için şu özetle yetinmiştir:

18 'inci asırda kayda değer bir şahsiyet yetiştirmeyen Azeri lehçesinde, Fuzuli'den sonra zikredebileceğimiz ilk şair Vâkıf'tır. Rus istilasına kadar Azerbaycan, tamamıla İran nüfuz ve tesiri altında idi... Rus istilasıyla beraber, Rus medeniyet, ilim ve edebiyatına temayül başladı.

19'uncu asrın engin millî temayülleriyle Azerbaycan'da milliyetperver bir gençlik yetişti. Bunlar İran tesirinden kurtulan ve garp temayüllerini taşıyan bir edebiyat yaratmaya uğraştılar. Epey de muvaffak oldular. Bu arada Vâkıf aruz ve hece ile yazdığı sade manzumeleriyle şöhret kazandı. Milli cereyanının başında Mirza Fetih Ahundof vardır. Fetih Ali, Avrupa şekil ve edebiyatını ilk defa Azeri lehçesine getiren simadır.

Milliyet ve Garplılık cereyanının bu ilk mümessili, hususi bir kıymete maliktir. Hulaseten gösterdiğimiz şekilde başlayan yeni ve milli Azerbaycan edebiyatı, Fetih Ali ile ayn yolda yürüyen Zakir ve Sabir'in eserleri sayesinde daha fazla kıymetlendi (Benderlioğlu 1937: 115-116).

Ne var ki bu eserde, 20. yüzyılın ilk çeyreğinde Azerbaycan ve Türkistan'ın bütün önemli merkezlerinde gelişme gösteren edebiyat ve kültürel hareketlilik hakkında en küçük bilgi kırıntısı bulmak mümkün değildir. Türkiye'deki edebiyat bahislerinde kitabın ilk baskısında bulunmayan bazı eser isimleri ikinci baskıya ilave edilecek kadar ${ }^{3}$ ayrıntıya girilmişken Türkiye dışındaki Türk edebiyatından hemen hiçbir şey yoktur. Bu durumun birinci sebebi, Rusya'da ve işgal ettiği coğrafyalarda Sovyet rejimi kurulduktan sonra Türkiye ile edebî ve kültürel ilişkilerin kesilmesi yani bilgi eksikliğidir.

Sadettin Nüzhet Ergun'un Tanzimat'a Kadar Mubtasar Edebiyat ve Edebiyat Tarihi ve Numuneleri (1931) kitabında, Türk edebiyatının ortak devirlerinin dışında, bütün Türk lehçe ve coğrafyalarının edebî ve kültürel birikimi, tarihî 
akış içinde verilmiştir. Bir başka ifade ile Fuat Köprülü’nün Türk Edebiyatı Tarihi (1920-1921)'ndeki dil ve millet merkezli bakış açısını burada da görmek mümkündür. Nitekim yazar "Kitabın tarihî kısmı için en ehemmiyetli mehazımız Pr Dr Köprülüzade Mehmet Fuat üstadımızın muhtelif eser ve makaleleridir." (5) demektedir. Farklı lehçelerin ortaya çıkışından sonraki dönemlerin Osmanlı sahası dışındaki edebî verimleri, eksiksiz olarak yansıtılmıştır.

Yine Sadettin Nüzhet' in Edebiyat ve Edebiyat Tarihi Özü (1935) adlı eserinde ise Türkiye dışındaki Türk edebiyatına sadece 15. yüzyıla kadarki bölümlerde yer verilmiştir. Muhtemelen diğer asırlar, yazılamayan sonraki ciltlere bırakılmışır.

Türkiye'deki edebî ve kültürel oluşumlarla eş zamanlı olarak Türk dünyasının diğer sahalarında neler olup bittiğini göstermek bakımından en ileri seviyedeki yazar, Agâh Sırrı Levent'tir.

Cumhuriyet döneminde liseler için yazılmış edebiyat tarihi ders kitaplarının en önemlisi Agâh Sırnı Levend'e ait Edebiyat Tarihi Dersleri (I. C. 1932, II. C. 1934, III. C. 1938) adlı kitaptır. Yukarıda Türkiye dışındaki Türk edebiyatlarına dair bilgi veren bütün edebiyat tarihi ders kitapları gibi bu eserin de Tanzimat'a Kadar olan I. Cildinde İslamiyet Öncesi ve İslami devir Türk edebiyatının çeşitli sahalardaki gelişimi anlatılmıştır.

Agâh Sırrı'nın bu eserinin "Servetifünun" açıklamalı III. cildi ise diğer bütün edebiyat tarihi ders kitaplarından farklı olarak Türkiye dışındaki Türk edebiyatını 1920’li yıllara kadar getirmiştir ki bu kısımlar diğer eserlerde olduğundan çok daha hacimlidir. Eserin diğer -ve belki daha önemli- bir farklılığı da anlatımdaki üslubudur. Yazar, Türk dünyasının kültürel bütünleşmeye varması için içtenlikli bir dili tercih etmiştir. "Azeri Edebiyatı" başlıklı bölüme girilirken

“... xix uncu asrın ilk yarısına ait vaziyeti hülasa ederken Vedadi, Vakıf, Zakir ve Mirza Fethali gibi şairlerden bahsetmiş ve Azeri edebiyatının o devre ait manzarasını çizmiştik. Şimdi de Büyük harbe kadar olan vaziyeti hülasa edeceğiz" (344).

diyerek Mirza Fethali Ahudzade’nin açtığı çığıı Necef, Neriman, Abdurrahim gibi şairlerin tiyatroya önem verişinden bahsetmektedir. Ayrı bir bahis açarak Seyit Azim Şirvani ve onun takipçileri Zakir, Mirza Ebülkasım Nebati ve İskender Ağa’nın edebiyatı yenileştirmedeki hizmetlerinden söz 
etmektedir. Azerbaycan'ın kadın şairlerinden Hurşit Banu’yu tanıtması da konuyla ilgili özel bir dikkat ve araştırmanın eseridir.

Satirik (mizahi) edebiyatın en büyük temsilcilerinden Sabir hakkında yazdıkları, bugün bile bir ders notu çerçevesini aşan bilgilerdir:

(...) Feridun Göçerli ile tanıştıktan sonra çalışmasını arttırmış ve Molla Nasrettin gazetesi çıkmaya başlayınca 15 'inci numaradan itibaren intişar eden hicviyelerini, mizahi yazıları ve içtimai dertleri teşrih eden manzumeleriyle kendini tanıtmıştır. (...) Sabir bu manzumelerde "Hop Hop" imzasını kullanmıştır.

Sabir milliyetperver bir şairdir. Bununla beraber sosyalist fikirlere de temas etmiştir. Fakat daima cehalet ve taassupla mücadele etmekten çekinmemiştir. Meşrutiyet'ten sonra 31 Mart irticaını evvelden haber vermiştir:

Osmanlılar aldanmayın Allah'ı seversen diyerek bizi ikaz etmek istemiştir.

Sabir mukallit değildir. Hicviyelerinde nezaketten ayrılmamıştır. Molla Nasrettin'den başka Hayat, Dibistan, İrşat, Güneş, Seda, Hakikat, Yeni Hayat, Malumat gibi mecmua ve gazetelerde manzumeleri çımıştır. "Hop Hop"tan sonra 'Din Direği”, "Mir'at", "Fazıl" ve daha birçok imzalarla yazmaya mecbur olmuştur. Bununla beraber yine halkın hücumlarından kurtulamamış ve esnafın boykotuna uğramıştır. Nihayet yeni usûlde okutmak üzere bir muallimle birlikte Mekteb-i Ümit'i açmış ise de bunu da bırakmaya mecbur olmuş ve 1910 'da Bakü'ye giderek orada muallimlik yapmıştır. Ölümü 1911'de Şamahi'dedir (Levend 1938: 349).

Liseler için yazılmış diğer edebiyat tarihi kitaplarında çoğunlukla yazar veya şair adı, bazen de eser isimleri verilip geçilmişken Agâh Sırrı Levend, her bir devri hâkim ruh ve zihniyet bakımından da tanıtmış ve -varsa- basın organlarının yayın çizgisinden de bahsetmiştir. Aşağıda alıntılanan metinde, Azerbaycan'ın 19. yüzyılın sonları ile 20. yüzyılın başlarındaki edebiyat ve basın ortamından bahsedilmektedir: 
Bu devirde gazete ve mecmuaların da halkı uyandırmak hususunda büyük bir rolü olmuştur. Azerbaycan'da çıkan ilk gazete Zerdaplı Melekzade Hasan tarafindan tesis edilen Ekinci gazetesidir. 1877'de Çar idaresi tarafından kapatılan bu gazeteyi Tiflis'te 1870 'de Ziya gazetesi takip etmiş sonra da Ziya-yı Kafkas adını alan bu mecmua bilhassa harflerin ıslahı meselesiyle meşgul olmuştur. 1883'ten 1891'e kadar Tiflis'te çıkan bir de Şark Rus adıyla bir gazete tesis edilmiştir. Bu gazete sonraları Bakü’de çıkmaya başlamıştır. 1905 ihtilalinden sonra Rusya, istilası altında bulunan küçük milletlerin kalkınma gayret ve teşebbüslerini biraz müsamaha ile karşılamaya mecbur olmuştur. Bunun neticesi olarak da yeni yetişen nesil bir taraftan Avrupa kültürüne uymaya, diğer taraftan da milliyet fikirlerini benimsemeye başlamış ve bu suretle Azerbaycan'da bir uyanma hareket ve hamlesi meydana gelmiştir.

Bu devir, Azeri Edebiyatında Füyûzat edebiyatı devresidir.

1905 'ten sonra Zeynel Abidin tarafından neşredilen Hayat gazetesini müteakip 1906 'da yine Zeynel Abidin tarafından Hüseyinzade Ali'nin idaresi altında çıkan Füyuzat mecmuasının tesiri çok büyük olmuştur. $\mathrm{Bu}$ mecmua etrafında toplanan gençler yeni bir edebi hareket meydana getirdiler. Bu edebiyat şekil ve estetik bakımdan bizim Serveti Fünun edebiyatını takip ediyordu. Fakat ruh ve mahiyet itibariyle hayati zaruretlerin tesiri altında halkçı ve milliyetçi idi. Gerçi bu milliyetçiliğe tamamıyla şuurlu, nüfuzlu denemez; fakat herhalde muhitte yaptığı tesir oldukça mühimdir. Bu edebiyatla garp edebi nevi ve şekilleri Azeri edebiyatında yerleşmiş olduğu gibi edebi meslek ve mekteplerin tesirleri de görülmeye başlamıştır. Füyuzatçıların kullandığı lisan da Servet-i Fünuncuların kullandığı lisandır ki birçok istihaleler geçirdikten sonra nihayet bugünkü Azeri lisanını meydana getirmiştir.

Mehmet Hadi ve Hüseyin Cavit şiir ve manzum tiyatro vadisinde kendisini göstermiş şahsiyetlerdendir. İlk şiirlerini Firdevs-i İlhamat adıyla toplayan Mehmet Hadi önceleri Tevfik Fikret'in tesirine maruz kalmışsa da sonraları Azeri muhiti- 
nin ihtiyaçlarına cevap vererek sosyal eserler meydana getirmiştir. Romantik ve idealist olan Hadi ile Hüseyin Cavit'ten bugünkü edebiyatımızda da bahsedeceğiz.

$\mathrm{Bu}$ devirde Tiflis'te Mehmet Kuluzade Celil tarafından çıkarılan Molla Nasrettin adlı mizah mecmuasının Azerbaycan'ın uyanış tarihinde çok mühim rolü olmuştur. Bu mecmua 1920'de Tebriz'e ve 1922'de Bakü'ye nakledilmiştir (1938: $350)$.

Agâh Sırrı Levend'in bir lise ders kitabı olduğu hâlde "Türkistan'da Vaziyet" başlığı altındaki şu tespitleri, hem bilimsel tavır hem de Türk dünyasının kültürel bütünleşmesi yolunda teşvik edici bir üslup taşımaktadır:

Çağatay Edebiyatının intişar etmiş olduğu geniş saha 16’ncı asırdan sonra müteaddit hanların birbirine karşı yaptıkları dâhili mücadelelere sahne olmuştur. Bir taraftan bütün şiddetiyle devam eden bu sürekli mücadeleler, diğer taraftan mutaassıp medrese zihniyetinin halk kitlesi üzerinde yaptığ tazyikler, Türkistan'ı büyük bir cehalet içinde bırakmıştır. On milyon nüfusun yüzde sekseninin okuyup yazma bilmemesi bu cehaletin ne kadar koyu ve feci olduğunu gösterebilir. Bu vaziyet içinde bir vakitler Ali Şir Nevayi gibi Türk şiirinin en büyük şahsiyetlerinden birini yetiştiren Çağatay Edebiyatı, kendini devam ettirecek şahsiyetlerden mahrum kalmış ve nihayet Babür Şahıtan sonra bu edebiyatın izleri ortadan kaybolmuştur. Azerbaycan sahasında olduğu gibi artık burada da Türkçe yerine Farsçanın katri hâkimiyetini görmüş oluyoruz. 1885 'te başlayan Rus istilası, Türkistan'ı işte bu vaziyette buldu. Vaktiyle en büyük medeniyet merkezlerinden biri olan Buhara da 1868 'te tam istiklalini kaybedince Türkistan'ın mukadderatı değişmiş, nihayet 1884'te Merv'in işgaliyle bu istila tamamlanmıştır.

İstiladan sonra Türkistan'ı Rusyarya bağlayan demiryolunun yapılması, Türklerin, Rus kültür ve hayatıyla temasını temin eden ilk amil olmuştur. Ruslar, istila siyasetlerini tatbik için ilk iş olarak, Türkistan'ın merkezi olan Taşkentıte Türkistan 
Vilayet gazetesi adlı hem mahalli lehçe hem de Rusça bir gazete neşrine başladılar.

Türkistan'da ilk uyanma hareketi, 1905 Rus ihtilali üzerine başlar. Rusya’nın mağlubiyetiyle neticelenen Rus-Japon Harbinin doğurduğu bu ihtilal, Azerbaycan sahasında olduğu gibi Türkistan'da da istila altında bulunan Türkler için nisbî bir serbestlik getirmiş oldu. Nitekim Türkistan'da küçük bir matbaanın tesisi ve mahalli lehçe ile Terakki adlı haftalık bir gazetenin neşri bu tarihe rastlar. Bunu Hurşit ve Şöhret daha sonra da Asya adlı gazeteler takip etmiştir.

Bu devirde Kırım'da çıkan Tercüman gazetesiyle İstanbul gazete ve mecmualarının da Türkistan münevverleri üzerindeki tesiri kaydedilebilir. Nihayet 1908'de Türkiye'de Meşrutiyet'in ilanı milliyet fikirlerinin ve milli şuurun Türkistan'da da uyanmasına hizmet etmiş oldu. Bu tesirle Buhara'da Turan adlı bir gazete neşredildi. Fakat gerek bu gazete, gerek bundan evvel ve bunu takip eden gazeteler Rus idaresi tarafından arka arkaya kapatılıyor, milliyet fikirlerinin ve uyanma hareketinin önüne geçilmek isteniyordu.

Rus istilasının manevi cephesini kuvvetlendiren, muhitte her yeni hareketi koyu ve korkunç bir zihniyetle karşılayan mutaassıp zümre olmuştur. Binaenaleyh Türkistan münevverleri, bir taraftan çar idaresinin tazyikine diğer taraftan da mutaassıp zihniyete karşı koymak gibi iki cepheli bir mücadeleye girişmek mecburiyetinde kalmışlardır. Bütün bu tazyiklere ve mukavemetlere rağmen, uyanma hareketi -yavaş da olsa- devam etmektedir (Levend 1938: 350-351).

Orhan Rıza Aktunç'un lise ve öğretmen okulları için yazdığı Türk Edebiyatı Tarihi -Kaynaklardan Bugüne Kadar (1934) kitabı, Türkiye dışındaki Türk lehçeleriyle meydana getirilmiş edebiyata yer vermek bakımından yukarıda bahsedilenlerden bir adım daha öndedir. Orhan Rıza, ortak dönem olan İslamiyet öncesi edebiyat, kültür ve toplumsal hayat bilgilerini özetledikten (5-21) sonra "İslam medeniyeti tesiri altında Türk edebiyatı" başlıklı Arap, Fars ve Türk edebiyatlarının ilk dönemleri hakkında bilgi aktarır. Konu- 
muz açısından önemli kısım ise Türkistan'da Tasavvuf başlıklı III. kısımdır. Burada, Türkistan'da başlayan Yeseviliğin Anadolu’ya kadar uzanışı konu edilerek Türk dünyasının o çağlardaki kültürel ortaklığı üzerinde durulmuştur. Aynı kısımda bulunan "Klasik edebiyatın inkişafı ve İbetülhakayık", Karahanlılar devri, Harizem sahası, Selçukîler devri Türk lisan ve edebiyatı gibi bahisler de vardır. "İslamlıktan sonra tahrir lehçeleri" başlıklı IV. Kısım ise doğrudan "Türk dünyası kültür bütünleşmesi” denebilecek bir bakış açısıyla yazılmıştır. Orta dereceli bir okulda öğrencinin Özbek-Uygur sahasından (Çağatay edebiyatı) Azerbaycan’a, Anadolu’ya, Irak’a uzanan bir edebiyatı ve Sekkâkî̀den Ahundof'a, Sabir'e gelen edebî mirası öğrenmesi, Türk dünyası kültürel bütünlüğü için azımsanamayacak öneme sahiptir. Bunlara VIII. Kısım'da "Batı medeniyeti çevresindeki şimal Türklerinin edebiyatı", Rus edebiyatı ve Türklere tesiri” gibi başlıklarla Abdülkayyum Nasırî, Gaspıralı İsmail Bey, Ayaz İshaki ve Abdullah Tokayif gibi ediplerden bahsedildiğini de eklemeliyiz.

Mustafa Nihat Özön Metinlerle Muasır Türk Edebiyatı Taribi’nde (1934) ve Son Asır Türk Edebiyatı Tarihinde (1941), sadece Türkiye'deki edebiyat ve kültürel hareketlerle ilgilenmekle yetinmiş, Türk dünyasının başka hiçbir bölgesine bakma gereği duymamıştır.

Celal Tahsin ve M. Asım imzalı Edebiyatı Tarihi Dersleri (1934) adlı lise 3. sınıf ders kitabı da Mustafa Nihat Özön'ün edebiyat tarihleri gibi sadece Tanzimat sonrasında Türkiye'deki edebî hareketliliği değerlendirir ve ayrıca eş zamanlı olarak Batı edebiyatı hakkında bilgiler verir.

Hıfzı Tevfik Gönensay ve Nihat Sami Banarlı'nın birlikte hazırladıkları Başlangıçtan Tanzimat’a Kadar Türk Edebiyatı Taribi (1941) adlı çalışma, ders kitabı değil liselerin 10. sınıfları için yardımcı kitaptır. Eserde Türkçenin lehçelere ayrılmadığı dönemlerin ortak edebiyat ve kültürüne temas edildiği gibi "İslam medeniyeti çağlarındaki ilk Türkçülük hareketleri” de gösterilmeye çalışılmıştır. Ayrıca her bir asrın kültür ve edebiyat hareketleri incelenirken önce o asrın bütün Türklük için arz ettiği manzara ortaya koyulmuş ve daha sonra farklı lehçelerin şahsiyet ve eserleri için ayrı birer alt başıı açılmıştır. Eserin ortak Türk edebiyatı için verdiği son başlık, "XIX uncu asrın birinci yarısında Türk edebiyatı"dır. Fakat kitabın yalnızca Hıfzı Tevfik Gönensay tarafından yazılan Tanzimat'tan Zamanımıza Kadar Türk Edebiyatı Tarihi (1945) adlı devamında söz konusu yöntemin 
terk edilip sadece Türkiye Türklüğünün kültür ve edebiyatına yer verildiği görülmektedir.

\section{Sonuç}

Türkiye'de yayımlanmış edebiyat tarihi ders kitaplarında bütün Türklüğe ait edebî ve kültürel verimlerin sergilenmesi, hem ilmî tavır hem de yetişme çağındaki nesiller için de milletinin medeniyet âlemine katkısını öğrenmek bakımından da yerinde bir tercih olmuştur. Bu tavır muhakkak ki bütün Türk soylular için geniş bir ailenin üyesi bulunma şuur ve gururunu yaşatmıştır. Bir bilim alanı olarak edebiyat tarihini, Osmanlı döneminin ilk edebiyat tarihlerindeki gibi devletin sınırlarıyla çevreleyip aynı dille başka sahalarda yazılanları yabancı saymak ne kadar yadırganması gereken bir tavırsa Türkiye Cumhuriyeti döneminde de en az o kadar bilim dışıdır. Çünkü o günkü bilgi noksanlığı, bazı eserlerde Türkiye dışına yönelmeyi verimsiz kılabilirdi. Ama iletişim vasıtaları gelişip bilgi teminindeki zorluklar ortadan kalktığı ölçüde aynı milletin farklı coğrafyalardaki edebî ve kültürel üretimine dönüp bakmamak, bilimsel tavırla izah edilemez. Ne var ki yukarıdaki açılklamalardan da anlaşılacağı üzere II. Dünya Savaşının etkileri görülmeye başladıktan sonra Doğu Türklüğü hakkında bir şey yazmak âdeta sakıncalı hâle gelmiş ve bu durum ta Sovyetler Birliği'nin çöküşüne kadar devam etmiştir. Bu iki zaman dilimi arasındaki nesillere, köklerinin Orta Asya'da olduğu okutulmuş, hatta 16. yüzyıla kadar ortak edebî verimlerden bazıları gösterilmiş ama 20. yüzyılda o coğrafyalarda Türk'ün bulunduğu söylenmemiştir. Diğer yandan Türk halkları arasındaki dağınıklık, Sovyet rejiminin de körüklemesiyle hızla birbirinden ayrılma ve farklı yazı dilleri oluşturma sürecini alevlendirmiştir. SSCB'nin dağılmasından sonra, lise edebiyat ders kitaplarına Türkiye dışındaki Türklügün girmesi, Türk dünyasının yarınki entegrasyonu için çok olumlu bir sonuçtur. 2017 yılında bütün Türk Cumhuriyetleri için hazırlanan ortak tarih ders kitapları gibi ortak edebiyat ve kültür tarihi ders kitapları da ivedilikle hazırlanıp okutulmalıdır.

\section{Açıklamalar}

11892 (1308)'de Londrảda toplanan Müsteşrikler Kongresi'nde bildiri olarak sunulmak üzere hazırlanan Tarihçe-i Lisan-ı Osmanî (Artin Asaduryan/ Şirket-i Mürettebiye Mat., İstanbul 1310 [1892]) Mehmet Fuat imzalıdır. A. Dilaçar (1968: 201) isim benzerliğinden dolayı eseri Köprülüzade Mehmet Fuat adına kaydetmiş, basım tarihini (1310) Rumi-Mali sayıp 
Miladi takvime "1894” olarak çevirmiştir. Fakat bu tarih doğru olsa bile Köprülüzade Mehmet Fuat o sıralar henüz dört yaşındadır.

2 Müftüoğlu Ahmet Hikmet Bey (1870-1927) kast ediliyor.

3 Mesela İsmail Habip Sevük hakkında, "edebiyat tarihi ve hususi üslûpla yazdığı makaleleriyle tanınmıştır. Tuna'dan Batıya seyahatnamesi çok güzeldir." (Benderliolu 1937: 192) deniyor. Benderlioğlu’nun kitabı ilk defa 1933'te yayımlanmış, 2. baskısı 1937'de yapılmıştır. 1935'te basılan Tuna'dan Batıya adı, doğal olarak ilk baskıda geçmemektedir.

\section{Kaynaklar}

Abdullah Şaik (Talipzade Abdulla Ahund Mustafaoğlu) (1924). Türk Edebiyyatı. Bakü: Azerneşr.

Abdülhalim Memduh (1888). Tarih-i Edebiyat-ı Osmaniye. İstanbul: Mahmutbey Matbaası.

[Aktunç], Orhan Rıza (1934). Türk Edebiyatı Tarihi-Kaynaklardan Bugüne Kadar. İstanbul: Sühulet Basımevi.

Akyüz, Yahya (1983). "Atatürk ve 1921 Maarif Kongresi”. Cumburiyet Döneminde Eğitim. Ankara: MEB Yay. 89-104.

Benderli, Muvaffak Hüsnü (1933). Edebiyat ve Edebiyat Tarihi. İstanbul: Cumhuriyet Kitaphanesi.

Celal Tahsin ve M. Asım (1934). Edebiyatı Tarihi Dersleri. İstanbul: Tecelli Matbaası.

Dilaçar, A[gop] (1968). Dil, Diller ve Dilcilik. Ankara: Türk Dil Kurumu Yay.

[Dilmen], İbrahim Necmi (1922). Tarih-i Edebiyat Dersleri. C. 1. Eski Edebiyatımızın Tarihine Seri Bir Nazar. İstanbul: Matbaa-i Amire.

[Dilmen], İbrahim Necmi (1922). Tarih-i Edebiyat Dersleri. C. 2. Edebî Teceddüdümüzün Zuhur ve Tekâmülü. İstanbul: Matbaa-i Amire.

Ergun, Sadettin Nüzhet (1935). Edebiyat ve Edebiyat Tarihi Özü. İstanbul: İnkılap Kitaphanesi.

F[aik] Reşat (1912). Tarih-i Edebiyat-ı Osmaniye. İstanbul: Zarafet Matbaası.

Gönensay, Hıfzı Tevfik ve Nihat Sami Banarlı (1941). Başlangıçtan Tanzimat'a Kadar Türk Edebiyatı Tarihi. İstanbul: Remzi Kitabevi.

Gönensay, Hıfzı Tevfik (1944). Tanzimat'tan Zamanımıza Kadar Türk Edebiyatı Tarihi. İstanbul: Remzi Kitabevi.

Kaplan, Mehmet, İnci Enginün ve Birol Emil (1978). Yeni Türk Edebiyatı Antolojisi. C. 1. İstanbul: İstanbul Üniversitesi Yay.

Köprülüzade Mehmet Fuat (1913, 1914). Türk Tarih-i Edebiyatı Dersleri (I. C 1329/1913, II. C 1330/1914). mübeyyizi: Darülfünun Ulum-1 Edebiye Şubesinden Hamit Sadi [Selen]. [taşbaskı] İstanbul. 
Köprülüzade Mehmet Fuat (1920-1921). Türk Edebiyatı Tarihi. İstanbul: Matbaa-i Amire.

Levend, Agâh Sırrı (1932). Edebiyat Tarihi Dersleri. C. I. Tanzimat’a Kadar. İstanbul: İstiklal Lisesi Talebe Kooperatifi Yay.

Levend, Agâh Sırrı (1934). Edebiyat Tarihi Dersleri. C. II. Tanzimat Edebiyatı. İstanbul: Marifet Matbaası.

Levend, Agâh Sırrı (1938). Edebiyat Taribi Dersleri. C. III. Servetifünun Edebiyatı. İstanbul: Kanaat Kitabevi.

[Özön], Mustafa Nihat (1934). Metinlerle Muasır Türk Edebiyatı Tarihi. İstanbul: Devlet Matbaast.

[Özön], Mustafa Nihat (1941). Son Asır Türk Edebiyatı Tarihi. İstanbul: Maarif Matbaasi.

Sevük, İsmail Habip (1925): Türk Teceddüt Edebiyatı Tarihi. İstanbul: Matbaa-i Amire.

Sevük, İsmail Habip (1932). Edeb̂̂ Yeniliğimiz Birinci Kısım -Tanzimat Edebiyatı. İstanbul: Devlet Matbaası, Maarif Vekâleti Yay.

Sevük, İsmail Habip (1932). Edeb̂̂ Yeniliğimiz İkinci Kısım. İstanbul: Devlet Matbaası, Maarif Vekâleti Yay.

Şahabettin Süleyman (1910). Tarih-i Edebiyat-ı Osmaniye. İstanbul: Sancakyan Matbaası.

Şahabettin Süleyman ve Köprülüzade Mehmet Fuat (1914). Yeni Osmanlı Tarih-i Edebiyatı-Menşelerden Nevşehirli İbrahim Paşa Sadaretine Kadar. İstanbul: Şirket-i Mürettebiye Matbaası. 


\title{
The Place of Secondary School History of Literature Textbooks vis a vis Turkic World Integration *
}

\section{Nâzım Hikmet Polat ${ }^{* *}$}

\begin{abstract}
Attributing arole in the direction of educational objectives to the history of literature is a consequence of modernity. The thought that history of literature should be considered along with the national identity, initially started in Western societies. In Turkey however, the attribution of such a function to history of literature dates back to the early 20th century after the Balkan wars. Early works on history of literature in Ottoman Era, in accordance with the ideology of Ottomanism, have dealt with literature only within the Ottoman territory and history and ignored both the literary outcome of Turkish language outside this territory and the accumulated literary treasure of even earlier times. It was Köprülüzade Mehmet Fuat who first followed the idea of "total Turkishness" in History of Literature Classes. During the Turkish Republic period until World War II, Turkish literature outside Turkey that is several Turkish dialects have been the subject of literature in the secondary school level. However, after World War II the Russians gained strength and this has been the greatest barrier to writing with the idea of total Turkishness in Turkey. In parallel to secondary education there has not been adequate interest in contemporary Turkish dialects in universities either. After the dissolution of the Soviet Union the interest for Turkish dialects has grown. These academic efforts will strengthen and speed up the integration of Turkic World.
\end{abstract}

\section{Keywords}

Ottomanism, history of literature, Balkan wars, Turkish dialects, Turkic World, integration.

\footnotetext{
* Date of Arrival: 24 September 2019 - Date of Acceptance; 17 October 2019

You can refer to this article as follows:

Polat, Nazım Hikmet (2019).”Türk Dünyasının Entegrasyonunda Lise Edebiyat Tarihi Kitaplarının

Yeri”. bilig-Journal of Social Sciences of the Turkic World 91: 255-278.

"* Prof. Dr., Ankara Hacı Bayram Veli University, The Faculty of Letters. The Department of Turkish Language and Literature - Ankara/Turkey

ORCID ID: https://orcid.org/0000-0001-5734-9308

nazim.polat@hbv.edu.tr
} 


\section{Роль учебников литературы для старших классов в интеграции юркского мира}

\section{Назым Хикмет Полат ${ }^{* *}$}

\section{Аннотация}

Придание определенной роли истории литературы с точки зрения целей образования является одним из следствий современности. Впервые идея о рассмотрении истории литературы в связи с национальной идентичностью возникла в западных обществах. Что касается Турции, то подобный подход к истории литературы наблюдается у нас только с начала $r \cdot$ века, вскоре после балканских войн. Первые истории литературы, относящиеся к периоду Османской империи, в соответствии с идеологией османизма сосредоточивались только на памятниках литературы, возникших на османских территориях в османский период, а произведения, написанные на тюркских языках в других регионах, a также более ранние памятники не входили в круг интересов.

Впервые идея о «всем тюркском» прозвучала в «Учебнике по истории литературы» (Тарих-и Эдебият Дерслери) Мехмеда Фуада Кёпрюлюзаде. В республиканский период вплоть до начала Второй мировой войны в преподавании турецкой литературы уделялось внимание тюркской литературе регионов за пределами Турции, то есть литературе на различных тюркских языках и диалектах. Однако усиление позиций Советского государства после Второй мировой войны стало главным препятствием для создания истории литературы с позиций «всего тюркского». Вслед за средним образованием и в университетах не было уделено достаточного внимания современным тюркским языкам. После развала Советского Союза интерес к тюркским языкам стал расти. Данный научный интерес будет способствовать интеграции тюркского мира и ускорит ее.

\section{Ключевые слова}

османизм, история литературы, Балканские войны, тюркские языки, тюркский мир, интеграция

\footnotetext{
* Поступило в редакцию: 24 сентября 2019 г. - Принято в номер: 17 октября 2019 г. Ссылка на статью:

Polat, Nâzım Hikmet (2019). “Türk Dünyasının Entegrasyonunda Lise Edebiyat Tarihi Kitaplarının Yeri”. bilig - Журнал Гуманитарных Наук Тюркского Мира 91: 255-278.

** Проф., д-р, Университет Хаджи Байрам Вели, Анкара, филологический факультет, кафедра турецкого языка и литературы - Анкара/Турция ORCID ID: https://orcid.org/0000-0001-5734-9308 nazim.polat@hbv.edu.tr
} 